\section{Prof. Atubi,} Augustus

\section{Osoyibo, Joseph*}

Ph. D., Department of Geography and Regional Planning, Delta State University, Abraka, Nigeria

Department of Geography and Regional Planning, Delta State University, Abraka, Nigeria *Corresponding Author

This study investigated the levels and spatial distribution of key air quality parameters within Asaba and environs. Five locations were sampled to assess the concentration of Nitrogen dioxide (NO2), Sulphur dioxide (SO2), hydrogen sulphide (H2S), carbon monoxide (CO) and volatile organic compounds (VOCs). Measurement of Air pollutants methods approved by ASTM was adopted for each specific parameter. All equipment and meters were properly precalibrated before each usage for quality assurance. Findings of the study showed that measured levels of CO (0.08-0.20 ppm), H2S (0.01-0.10 ppm) and VOCs (13-20 ppm) in all sampling areas were below World Health Organization (WHO) and National Air Quality (NAQ) Guidelines and Standards for ambient conditions. However, NO2 (0.11-0.25 ppm) in all sampling areas was quite high and above regulatory limits. SO2 (0.15-0.25 ppm) was within the acceptable limit in Okwe and Ibusa but above regulatory limits in Asaba, Anwai and Okpanam. The results suggest Routine measurements should be made on a continuous basis to ascertain the volume of gaseous pollutants in the urban and rural environments

\section{INTRODUCTION}

Air pollution is a major environmental health problem affecting everybody, both in developed and developing countries which has a serious significant impact on the ecosystem and the health of humans. This type of pollution can be defined as the presence of pollutants concentration, such as particle substances (PM), sulphur dioxide (SO2), nitrogen oxides (NOX) and ozone (O3) in the air that is inhaled at levels which can create some negative environmental and human health (Yelda \& Mustafa, 2011) as well as major environmental risk factor in the incidence and progression of some diseases such as respiratory diseases, asthma, pneumonia, asthma, lung cancer, ventricular hypertrophy, psychological complications, autism, retinopathy, fetal growth, tuberculosis, meningitis and measles and low birth weight (Ghorani-Azam, Riahi-Zanjani \& Balali-Mood, 2016). There are both natural and human-based sources of air pollution. However, humans contribute significantly more to the problem of air pollution in the environment.

Human health is endangered with diseases associated with this nature of pollution particularly in developing economies facing industrialization and urbanization rapidly resulting in early mortality. However, by reducing the levels of this air pollution, countries can reduce the burden of diseases from respiratory diseases, asthma, pneumonia, tuberculosis, Meningitis to measles (WHO, 2014). The reduction in outdoor air pollution caused by emissions from vehicles, electricity generators and industries, road and building construction activities, as well as mining etc reduces Carbon dioxide (CO2) emissions and this short-lived climate pollutants such as the particles of a black carbon and methane, consequently contributing to near and long term mitigation of climate change in the environment (WHO, 2014).

Globally, air pollution poses a serious threat to human health and the ecosystem generally. (Adejoke, Andile \& Murembiwa, 2019). Economic growth, urbanization, energy generation and consumption, transportation services and rapid population growth are major energetic forces of air pollution resulting in various health consequences that affect children the most, as they are the most vulnerable (Colbeck \& Lazaridis, 2010). Due to this effect, air pollution has become one of the most significant environmental and public health issues.

Air contamination is a leading environmental
toxin(Landrigan, Fuller, Acosta, Adeyi, Arnold, Basu, Zhong, 2017) attributed to diseases responsible for an estimated $16 \%$ of premature deaths in the world. In recent years, several epidemiological studies in both developed and developing countries (Nwachukwu \& Ugwuanyi, 2010; Yelda \& Mustafa, 2011; Nwachukwu, Chukwuocha \& Igbudu, 2012; Lelieveld, Klingmuller, Pozzer, Poschl, Fnais, Daiber \& Munzel, 2019) have occurred, showing short-term and long-term exposure to air pollutants and its adverse associated health effects. Similarly, time series studies conducted in Asian cities also showed effects of exposure to particulate matter such as NO2, SO2, O3on mortality to those explored in Europe, South America and Africa (Vlatka, Elvira \& Josip, 201 1;William, 2012; Menezes, Viana \& Paes, 2012; Ibe, Opera, Njoku \& Alinno, 2017; Lelieveld et al., 2019).

In Africa and Nigeria in particular, Ibe et al., (2017) monitored ambient air quality of industrial areas of Southeastern Nigeria for criteria pollutants which included Particulate matter (PM10), sulfure (SO2), Nitrogen dioxide (NO2) as well as Carbon monoxide (CO) and all the pollutants monitored were found to be very high as compared to the World Health Organization Air Quality Guideline. This means that these pollutants are already of a high risk to the teeming Nigerian population. Yelda and Mustafa (2011) examined air pollutants and its possible health effects. The results of the study showed an increase in respiratory tract diseases of an AntigenPresenting Cells (APCs).Nine-year data analysis results obtained showed a significant relationship between the APCs and respiratory tract diseases. That is, as the APCs (SO2 and $\mathrm{PM}$ ) increases, so does the morbidity and number of respiratory tract diseases. According to the findings, respiratory tract infections are significantly related to SO2 and PM concentrations.

Despite putting considerable air pollution prevention and control measures in recent years into practice, outdoor air pollution remains one of the most significant threat to humans (Sun \& Zhu, 2019) which is regarded as one of the greatest public health threats worldwide. Depending on sizes and nature, all constituents appearing in excess quantities in the atmosphere, such as particulate matter, sulphur oxides as well as nitrogen oxides may be its ingredients.People's exposure to these pollutants may cause greater risk of acute cardiovascular diseases, respiratory tract diseases, and increased mortality. Also, the

\begin{tabular}{|c|c|c|}
\hline Submitted : $12^{\text {th }}$ October, 2019 & Accepted : 23 ${ }^{\text {rd }}$ November, 2019 & Publication : 15 $^{\text {th }}$ February, 2020 \\
\hline wwww.worldwidejournals.com $\mid$ & & \\
\cline { 2 - 2 }
\end{tabular}


penetration of smaller particles may act as brain's blood obstruction and thus affect the central nervous system (G adka, Rymaszewska \&Zato ski,2018).

However, much attention has not been given to environmental air pollution but few scholars have been looking at only oil producing communities (Ogbija, 2014, Atubi, 2015a, Atubi, 2015b), for example Ogbija (2014) looked at the effects of environmental degradation on human health in oil producing communities in Delta State while Atubi (2015 a \& b) looked at the factors of environmental degradation in oil producing communities in Delta State and the effects of oil spillage on human health in oil producing communities in Delta State. Hence, the emphasis on only oil producing communities restricted the purview of the study. This is because researches by (Hathout, 2002; Gruzieva, 2013; Baumgartner, 2014) have shown that the vertical and lateral movement of air leaves unpolluted source communities vulnerable to air pollution problems. Therefore, this research is set to examine the prevalence of pollutant gases and the occurrence of associated diseases in Asaba Metropolis, Delta State since air quality research in this area is scarcely available or very scanty.

\section{Research Methods}

Epidemiological data of all the reported cases treated for airpollution related diseases from 2008 to 2017 reported by place of diagnoses was obtained from the Federal Medical Centre (FMC) in Asaba and it is important to note that the data collected from the FMC represent the sum of the incidences from all the hospitals within both local government areas. The Air-pollution related diseases were extracted from medical records from 2008 to 2017 based on reliability, consistency, continuity in records and long range of data as seen in Nwachukwu et al., (2012), Atubi (2015 a and b). The major diseases associated with air pollution that was investigated are respiratory diseases, Asthma, Pneumonia, Tuberculosis, Meningitis and Measles. These diseases are well defined in literature (Ugwuanyi \& Obi, 2002; Brooks, Carrol, Butel, \& Morse, 2007;Willy, Sherwood \&Woolverton, 2008).

The study adopted the stratified random sampling technique and it was applied based on the division of the study area. Study sites were selected with a view to giving a holistic representation of air quality status of the area. The study area was stratified into two LGAs based on presence of main roads, dump sites, industries, and residence and 3 sampled sites were delineated for Oshimili South and 2 for Oshimili North which make up Asaba Metropolis. The three communities sampled in Oshimili South are Asaba, Anwai while Okwe, Ibusa and

\section{DISCUSSION OF RESULTS/FINDINGS}

\section{Table 1:The Distribution of Air Pollutants in Oshimili North and South LGAs of Delta State.}

\begin{tabular}{|c|c|c|c|c|c|c|c|c|}
\hline \multirow{7}{*}{$\begin{array}{l}\text { Morning } \\
\text { Hours }\end{array}$} & \multirow{2}{*}{$\begin{array}{l}\text { Pollutants } \\
\text { (ppm) }\end{array}$} & \multicolumn{3}{|c|}{ Oshimili South } & \multicolumn{2}{|c|}{ Oshimili North } & \multirow{2}{*}{$\begin{array}{l}\text { WHO Standard } \\
\text { (ppm) }\end{array}$} & \multirow[t]{2}{*}{ NAQS (ppm) } \\
\hline & & Assaba & Okwe & Anwai & Okpanam & Ibusa & & \\
\hline & NO2 & 0.22 & 0.23 & 0.12 & 0.20 & 0.25 & 0.10 & $0.04-0.06$ \\
\hline & SO2 & 0.17 & 0.21 & 0.25 & 0.17 & $0.2 /$ & 0.175 & $0.01-0.10$ \\
\hline & $\mathrm{H} 2 \mathrm{~S}$ & 0.09 & 0.1 & 0.05 & 0.01 & $0.1 /$ & 22.4 & Nil \\
\hline & $\mathrm{CO}$ & 0.08 & 0.17 & 0.04 & 0.2 & 0.15 & 26 & $10-20$ \\
\hline & VOC & 20 & 15 & 14 & 16 & 16 & 30.3 & Nil \\
\hline \multirow{5}{*}{$\begin{array}{c}\text { Evening } \\
\text { Hours }\end{array}$} & NO2 & 0.21 & 0.22 & 0.11 & 0.20 & 0.23 & 0.10 & $0.04-0.06$ \\
\hline & $\mathrm{SO} 2$ & 0.16 & 0.20 & 0.24 & 0.15 & 0.2 & 0.175 & $0.01-0.10$ \\
\hline & H2S & 0.10 & 0.1 & 0.03 & 0.01 & 0.09 & 22.4 & Nil \\
\hline & $\mathrm{CO}$ & 0.2 & 0.15 & 0.05 & 0.08 & 0.14 & 26 & $10-20$ \\
\hline & VOC & 20 & 14 & 13 & 15 & 15 & 30.3 & Nil \\
\hline
\end{tabular}

Source:Authors field work, 2018

Table 1 shows the mean pollution load in the study areas during morning and evening hours. The result of air pollutant measured in the mornings showed that, Nitrogen Dioxide (NO2), , Sulfur dioxide (SO2), Hydrogen Sulphide (H2S), Carbon Monoxide (CO), and Volatile and organic compounds (VOC) have mean concentration of $0.22 \mathrm{ppm}, 0.17 \mathrm{ppm}$,
Okpanam were sampled in Oshimili North LGA (See figure 1). The air quality data was generated from measurement of NO2, $\mathrm{SO} 2, \mathrm{H} 2 \mathrm{~S}, \mathrm{CO}$ and VOC in the five locations. The National Ambient Air Quality Standard (NAAQS) data and the summary of the Updated World Health Organization Air Quality Guideline (WHOAQG) data were also collected for the purpose of comparison as secondary data.

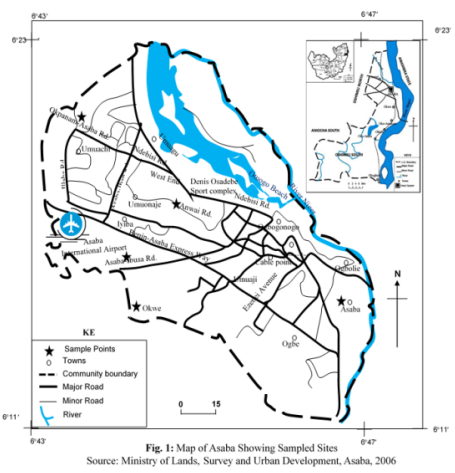

The types and trend of air pollutants/pollution in the study location, ambient air quality from the respective sites in the study location were analyzed descriptively (Mean \pm SD) and to determine the pattern and prevalence of pollutant gases. The descriptively (Mean \pm SD) has been used by Nwachukwu et al. (2012) to ascertain the effect of air pollution on the people of Rivers State, Nigeria, Ogbija (2014) to examine effects of environmental degradation on human health in selected oil communities and also by Atubi (2015b) to examine effects of oil spillage on human health in producing communities of Delta State,Nigeria.

On the prevalence of air pollution associated diseases, analysis of medical record using simple percentage method, frequency distribution method and measure of central tendency/dispersion (Mean \pm SD) was adopted to determine the pattern and prevalence of associated diseases.

To examine the relationship between the five prevalent pollutant gases and air pollution associated diseases in Asaba, data from medical records was regressed against volumes of prevalent pollutants in the area using Multiple Regression Model.The Multiple regression models were used to examine factors of environmental degradation (see Atubi, $2015 \mathrm{a \& b}$ ). Also, the multiple regression analysis has been applied in researches by Nkwocha, Egejuru, Pat-Mbano and Tony-Njoku (2011), Atubi (2011 and 2012), Atubi and Ogbija (2015) with significant results. the mean concentrations are $0.23 \mathrm{ppm}, 0.21 \mathrm{ppm}, 0.1 \mathrm{ppm}$, $0.17 \mathrm{ppm}$ and $15 \mathrm{ppm}$ for Nitrogen Dioxide (NO2), , Sulfur dioxide (SO2), Hydrogen Sulphide (H2S), Carbon Monoxide (CO), and Volatile and organic compounds (VOC) respectively in Okwe. For Anwai the mean concentrations recorded in the morning during the study period were $0.12 \mathrm{ppm}, 0.25 \mathrm{ppm}, 0.05 \mathrm{ppm}, 0.04 \mathrm{ppm}$ and $14 \mathrm{ppm}$ for 
Nitrogen Dioxide (NO2), Sulfur dioxide (SO2), Hydrogen Sulphide (H2S), Carbon Monoxide (CO), and Volatile and organic compounds (VOC) respectively.

In Okpanam, the mean concentration of $0.20 \mathrm{ppm}, 0.17 \mathrm{ppm}$, $0.01 \mathrm{ppm}, 0.2 \mathrm{ppm}$ and 16ppm for Nitrogen Dioxide (NO2), Sulfur dioxide (SO2), Hydrogen Sulphide (H2S), Carbon Monoxide (CO) and Volatile organic compounds (VOC) respectively while the mean concentrations for Ibusa were $0.25 \mathrm{ppm}, 0,2 \mathrm{ppm}, 0,1 \mathrm{ppm}, 0.15 \mathrm{ppm}$ and $16 \mathrm{ppm}$ were recorded for Nitrogen Dioxide (NO2), Sulfur dioxide (SO2), Hydrogen Sulphide (H2S), Carbon Monoxide (CO), and Volatile and organic compounds (VOC) respectively.

In the evening hours, the mean concentration of $0.21 \mathrm{ppm}$, $0.16 \mathrm{ppm}, 0.10 \mathrm{ppm}, 0.2 \mathrm{ppm}$ and $20 \mathrm{ppm}$ for Nitrogen Dioxide (NO2), , Sulfur dioxide (SO2), Hydrogen Sulphide (H2S), Carbon Monoxide (CO), and Volatile and organic compounds (VOC) were recorded in Asaba. In Okwe, the mean concentration of $0.22 \mathrm{ppm}, 0.20 \mathrm{ppm}, 0.1 \mathrm{ppm}, 0.15 \mathrm{ppm}$ and $14 \mathrm{ppm}$ were recorded for Nitrogen Dioxide (NO2), Sulfur dioxide (SO2), Hydrogen Sulphide (H2S), Carbon Monoxide (CO), and Volatile and organic compounds (VOC) respectively. At Anwai, the mean concentration recorded were $0.11 \mathrm{ppm}, 0.24 \mathrm{ppm}, 0.03 \mathrm{ppm}, 0.05 \mathrm{ppm}$ and $13 \mathrm{ppm}$ for Nitrogen Dioxide (NO2), , Sulfur dioxide (SO2), Hydrogen Sulphide (H2S), Carbon Monoxide (CO), and Volatile and organic compounds (VOC) respectively. Similarly at Okpanam, the mean concentration of $0.20 \mathrm{ppm}, 0.15 \mathrm{ppm}$, $0.01 \mathrm{ppm}, 0.05 \mathrm{ppm}$ and $15 \mathrm{ppm}$ were recorded for Nitrogen Dioxide (NO2), Sulfur dioxide (SO2), Hydrogen Sulphide (H2S), Carbon Monoxide (CO), and Volatile and organic compounds (VOC) respectively while the mean concentration of $0.23 \mathrm{ppm}, 0.2 \mathrm{ppm}, 0.09 \mathrm{ppm}, 0.14 \mathrm{ppm}$ and $15 \mathrm{ppm}$ for Nitrogen Dioxide (NO2), Sulfur dioxide (SO2), Hydrogen Sulphide (H2S), Carbon Monoxide (CO), and Volatile and organic compounds (VOC) respectively were recorded in Ibusa.

It could be deduced from the Table 1 that higher concentration of the Nitrogen Dioxide (NO2) in Ibusa was recorded in the morning hour and least in the evening hour. However, Anwai had the least concentration of the Nitrogen Dioxide (NO2), closely followed by Okpanam, Asaba and then Okwe. It should therefore be noted that combustion of fossil fuel is the primary source of NO2 emissions (Olajire, Azeez \& Oluyemi, 2011) in the study areas. The outcome of the finding showed that there is a high rate of combustion of fossil fuel taking place in Ibusa than any other study areas. Major sources of fossil fuel include transportation (including personal and heavy-duty vehicles), generation of electricity, industrial processes, residential and commercial activities. In additional to the finding, sources of biomass, coal smoke emissions and industries have been informed to emit many health-damaging pollutants, including nitrogen oxides (Akpoghelie, Irerhievwie, Agbaire \& Orisaremi, 2016). Studies have revealed that Nitrogen dioxide has the ability to irritate the lungs and lower resistance to respiratory infections such as influenza (Akpoghelieet al., 2016). Also, the outcome of the finding revealed that burning of fossil fuels such as coal, oil and natural gas was the main source of sulphur dioxide concentration in the areas sampled. General survey also showed that the exposure to sulphur dioxide occurs primarily through direct breathing of contaminated air (Akpoghelieet al., 2016).The Agency for Toxic Substance and Disease Registry (2016) reported a long-term study surveying large numbers of children and the finding revealed possible associations between SO2pollutant and symptoms of respiration or reduced ability of breathing. SO2 pollution may result in corneal haze, breathing difficulty, airway inflammation, eye irritation, psychic alterations, pulmonary oedema, heart failure and circulatory collapse.

From the result obtained from H2S in the five sampled locations, it could be seen that all values obtained for hydrogen sulphide (H2S) at different sampling locations were below the WHO Guidelines and Standards for Ambient Air Quality which stipulates a range of $22.4 \mathrm{ppm}$. This implies that there are low anthropogenic activities in the study areas emitting H2S to the atmosphere. Short-term exposure to H2S causes throat irritation, nose, eyes, tiredness, headaches, and breathing difficulties in asthmatic patients while long-term exposure may affectnervous system and respiratory tract (ATSDR, 2016).

From the results, it could be seen that Carbon monoxide (CO) measured at all the sampling locations was between the ranges of 0.08 to $0.20 \mathrm{ppm}$. This implies that the concentration of CO measured in all the sampling stations was below the WHO and NAQ standards tolerance limit for air quality, which stipulates a range of $26 \mathrm{ppm}$ and 10 to $20 \mathrm{ppm}$ for an 8-hourly average time respectively and therefore may not pose immediate hazard to the exposed population. It can also be deduced from the finding that Asaba and Okpanam had the highest joint $\mathrm{CO}$ concentrations value of 0.20 ppm recorded in the evening and morning sampling sessions respectively. Anwai had the lowest concentration value ranging from 0.04 to $0.05 \mathrm{ppm}$. This low concentration of $\mathrm{CO}$ is due to the fact that $\mathrm{CO}$ is certainly oxidized by oxygen to carbon dioxide in the atmosphere. Carbon monoxide levels in urban and semiurban areas closely reflect traffic density (in combination with weather conditions) and also open incineration of wastes (Njoku et al., 2016). In this study, the two highest CO concentrations were recorded at two major traffic intersection areas (Asaba and Okpanam), thisis mainly because of the high presence of vehicular activities and road construction along Federal Medical Center during the sampling period. The CO concentration in this study is quite different from those reported by Olajire et al. (2011) and Akpoghelie et al. (2016) in a study of air pollutants along Oba Akran road, Ikeja Lagos State and sub-urban cities in Isoko, Delta State.

The results of the study also revealed that the values of data for VOC concentrations in this study ranges from 13.00 to 20.00 ppm which falls below the maximum WHO standard (30.3 ppm) in fresh air which is safe for healthy adults for an 8-hour work day (WHO, 2016). It could be seen that Asaba had the highest VOC concentration with value of $0.20 \mathrm{ppm}$ showing a high traffic density and other anthropogenic activities taking place in Asaba main town than any of the sampled location. Anwai had the least concentration of the VOC, closely followed by Ibusa and Okpanam which had similar concentrations for both sampling periods and then Okwe. The World Health Organization (2018) reported that people are at highest risk of prolonged exposure to VOC from heavy motor vehicle traffic.

3.1: The Prevalence of Air Pollution and Associated Diseases 2007-2017.

Table 2: Patients care information statistics on Air Pollution Related Diseases Reported for the period of ten years (2008-2017)

\begin{tabular}{|c|c|c|c|c|c|c|}
\hline Year & $\begin{array}{c}\text { Respirato } \\
\text { ry } \\
\text { Disease }\end{array}$ & $\begin{array}{c}\text { asthm } \\
\text { a }\end{array}$ & $\begin{array}{c}\text { Pneumon } \\
\text { ia }\end{array}$ & $\begin{array}{c}\text { Tuberculo } \\
\text { sis }\end{array}$ & $\begin{array}{c}\text { Meningit } \\
\text { is }\end{array}$ & $\begin{array}{c}\text { Measl } \\
\text { es }\end{array}$ \\
\hline 2008 & 1386 & 99 & 91 & 148 & 3 & 21 \\
\hline 2009 & 2726 & 135 & 355 & 227 & 27 & 33 \\
\hline 2010 & 1402 & 84 & 122 & 2448 & 4 & 27 \\
\hline 2011 & 1902 & 241 & 310 & 274 & 12 & 35 \\
\hline 2012 & 2292 & 291 & 277 & 3197 & 9 & 23 \\
\hline 2013 & 2882 & 312 & 69 & 3716 & 3 & 19 \\
\hline 2014 & 1878 & 162 & 65 & 833 & 6 & 6 \\
\hline 2015 & 1635 & 100 & 82 & 749 & 5 & 8 \\
\hline 2016 & 1252 & 81 & 69 & 1029 & 21 & 13 \\
\hline 2017 & 1534 & 68 & 50 & 876 & 43 & 7 \\
\hline Total & 18889 & 1573 & 1490 & 13497 & 133 & 192 \\
\hline
\end{tabular}


Source: Department of Health Information Management, Federal Medical Centre, Asaba (2018)

Table 2showsdata on air pollution related diseases reported at the Federal Medical Centre, Asaba, a central medical facility covering the study areas. The result showedthat for the immediate past decade, respiratory diseases had the highest prevalence with total reported cases of 18,889 . This is closely followed by Tuberculosis with a ten year record of 13,497 , Asthma recorded 1,573 cases, Pneumonia cases were 1,490, Measles cases were 192 while the least reported disease was Meningitis with a ten year record of 133 cases.

The result further showed cases of respiratory diseases were on the increase from 1,386 in 2008 to 1,534 cases in 2017. Similarly, cases of Tuberculosis were on the increase from 148 cases in 2008 to about 876 cases in 2017. Same trend was observed for Meningitis, only 3 cases were recorded in 2008 but by 2017, the incidence had increased to 43 cases. However, it appeared to be a good decline in reported Measles cases from 21 cases in 2008 to 7 in 2017. This drift was also observed in Pneumonia which had 91 reported cases in 2008 but reduced to 50 in 2017 . There was also a marginal drop in the reported cases of Asthma for the period from 99 cases in 2008 to 68 in 2017.

It is pertinent to observe that phenomenal increases in the hospital cases of respiratory diseases were in 2009 where the figure rose to 2726 . In 2013 , the figure rose sharply to 2882 . From 2013 to 2017, the figures showed a downward trend. In a similar pattern, Tuberculosis had a peak in 2010 with reported hospital cases of 2448 which further rose to 3197 in 2012 and 3716 in 2013. The rest of the diseases didn't show these sharp increases and drop like respiratory diseases and Tuberculosis. There were fluctuations in the numbers of reported cases within the years but there were not very pronounced like that of the respiratory diseases and Tuberculosis in the area.

One could possible comment that most of the declines seen in reported cases could be attributed to availability and accessibility of drugs and medical care. Also, there have been massive awareness campaigns by Government and other health related ministries and agencies that people should seek early medical care for especially cases of Tuberculosis noting that early diagnosis is key to survival of patients.

\subsection{Relationship between Prevalence of Pollutants and Occurrence of Associated Diseases}

Table 3: Summarized Multiple Regression Model Result

\begin{tabular}{|c|c|c|c|c|}
\hline Model & $\mathrm{R}$ & $\begin{array}{c}\mathrm{R} \\
\text { Square }\end{array}$ & $\begin{array}{c}\text { Adjusted R } \\
\text { Square }\end{array}$ & $\begin{array}{c}\text { Std. Error of the } \\
\text { Estimate }\end{array}$ \\
\hline NO2 & $.727 \mathrm{a}$ & .529 & .413 & .05560 \\
\hline SO2 & $.790 \mathrm{a}$ & .624 & .129 & .03516 \\
\hline H2S & $.654 \mathrm{a}$ & .428 & .716 & .05084 \\
\hline CO & $.977 \mathrm{a}$ & .954 & .862 & .02204 \\
\hline VOC & $.803 \mathrm{a}$ & .645 & .064 & 2.46948 \\
\hline
\end{tabular}

a. Predictors: (Constant), Measles, Tuberculosis, Meningitis, Respiratory Disease , Asthma, Pneumonia

Table 3 presents the summarized R, R2, adjusted R2, and the standard error of the estimate, which was used to determine how well a regression model fits the air pollution and disease data.

The values of 0.727 for NO2, 0.790 for SO2, 0.654 for H2S, 0.977 for $\mathrm{CO}$ and 0.803 for VOC indicate a very high level of prediction of the relationship between air pollution and prevalence of associated diseases in Oshimili South and North LGAs as represented by Asaba and Okanam and other locations.

The $\mathrm{R} 2$ value (also called the coefficient of determination) is the proportion of variance in the dependent variable that can be explained by the independent variables. From the model result, values of 0.529 for $\mathrm{NO} 2,0.624$ for $\mathrm{SO} 2,0.428$ for $\mathrm{H} 2 \mathrm{~S}$, 0.954 for $\mathrm{CO}$ and 0.645 for VOC means that NO2 explains or account for $53 \%$ of the prevalence of Measles, Tuberculosis, Meningitis, Asthma, Pneumonia and respiratory diseases in the study area. SO2 accounts for $62 \%$, H2S accounts for $43 \%$, CO accounts for $95 \%$ and VOC accounts for $65 \%$ of the prevalence of Measles, Tuberculosis, Meningitis, Asthma, Pneumonia and respiratory diseases in the study areas. The result evidently shows that $\mathrm{CO}$ is the largest culprit in the atmospheric pollutants that contributes to diseases. This is followed closely by VOC. This result is congruent with the hospital data collected.

Table 4: Summarized ANOVAa

\begin{tabular}{|c|c|c|c|c|c|c|}
\hline Model & $\begin{array}{c}\text { Sum of } \\
\text { Squares }\end{array}$ & $\mathrm{df}$ & $\begin{array}{c}\text { Mean } \\
\text { Square }\end{array}$ & & \multicolumn{2}{|c|}{ Sig. } \\
\hline NO2 & Regression & .010 & 6 & .002 & .562 & $.749 \mathrm{~b}$ \\
\hline & Residual & .009 & 3 & .003 & & \\
\hline & Total & .020 & 9 & & & \\
\hline SO2 & Regression & .006 & 6 & .001 & .828 & $.615 \mathrm{~b}$ \\
\hline & Residual & .004 & 3 & .001 & & \\
\hline H2S & Total & .010 & 9 & & & \\
\hline & Regression & .006 & 6 & .001 & .374 & $.859 \mathrm{~b}$ \\
\hline & Total & .014 & 9 & & & \\
\hline CO & Regression & .030 & 6 & .005 & 10.353 & $.041 \mathrm{~b}$ \\
\hline & Residual & .001 & 3 & .000 & & \\
\hline & Total & .032 & 9 & & & \\
\hline VOC & Regression & 33.305 & 6 & 5.551 & .910 & $.580 \mathrm{~b}$ \\
\hline & Residual & 18.295 & 3 & 6.098 & & \\
\hline & Total & 51.600 & 9 & & & \\
\hline & Dependent Variable: NO2, SO2, H2S, CO, VOC \\
\hline
\end{tabular}

a. Dependent Variable: NO2, SO2, H2S, CO, VOC

b. Predictors: (Constant), Measles, Tuberculosis, Meningitis, Respiratory Disease , Asthma, Pneumonia

Table 4 show the summarized ANOVA generated from the multiple regression analysis. The F statistic of 0.562 for $\mathrm{NO} 2$ with p-value (sig. of 0.749 ), 0.828 for SO2 with p-value (sig. of 0.615 ), 0.374 for $\mathrm{H} 2 \mathrm{~S}$ and p-value (sig. of 0.859 ), 10.353 for $\mathrm{CO}$ with $\mathrm{p}$-value (sig. of 0.041 ) and 0.910 for VOC with $p$-value (sig. of 0.580 ) means that our model is significant. This implies that the gaseous pollutants have been able to predict the prevalence of the associated diseases, therefore the null hypothesis is rejected and an alternative hypothesis accepted that there is a relationship of significant between the volume of air pollutant gases and the occurrence of associated diseases in the study areas.

Table 5: Coefficients of the Multiple Regression for NO2Coefficientsa

\begin{tabular}{|c|c|c|c|c|c|c|}
\hline \multicolumn{7}{|c|}{ Coefficientsa } \\
\hline \multirow{2}{*}{\multicolumn{2}{|c|}{ Model }} & \multicolumn{2}{|c|}{$\begin{array}{c}\text { Unstandardized } \\
\text { Coefficients }\end{array}$} & \multirow{2}{*}{\begin{tabular}{|c|}
$\begin{array}{c}\text { Standard } \\
\text { ized } \\
\text { Coefficie } \\
\text { nts }\end{array}$ \\
Beta \\
\end{tabular}} & \multirow[t]{2}{*}{$\mathrm{t}$} & \multirow[t]{2}{*}{ Sig. } \\
\hline & & B & Std. Error & & & \\
\hline \multirow[t]{7}{*}{1} & (Constant) & .126 & .081 & & 1.566 & .215 \\
\hline & $\begin{array}{c}\text { Respiratory } \\
\text { Disease }\end{array}$ & $-9.638 \mathrm{E}-7$ & .000 & -.012 & -.018 & .987 \\
\hline & Asthma & .000 & .000 & .883 & 1.107 & .349 \\
\hline & Pneumonia & $-5.515 E-5$ & .000 & -.138 & -.149 & .891 \\
\hline & Tuberculosis & $-1.202 E-5$ & .000 & -.332 & -.567 & .611 \\
\hline & Meningitis & .002 & .002 & .614 & 1.224 & .308 \\
\hline & Measles & $-5.673 E-5$ & .003 & -.013 & -.016 & .988 \\
\hline & & Depend & Varial & NO2 & & \\
\hline
\end{tabular}


PARIPEX - INDIAN JOURNAL OF RESEARCH | Volume-9 | Issue-2 | February - 2020 | PRINT ISSN No. 2250 - 1991 | DOI : $10.36106 /$ paripex

Table 5 presents the Coefficients of the Multiple Regression for NO2 and diseases recorded in Oshimili South and North Local Government Areas. From the standardized coefficient values in Table 5, the beta values are positive for Asthma and Meningitis meaning that as the emission of NO2 gases increases so also the occurrence of Asthma and Meningitis increases.

\section{Table 6: Coefficients of the Multiple Regression for So2}

\begin{tabular}{|c|c|c|c|c|c|c|}
\hline \multicolumn{2}{|c|}{ Model } & \multicolumn{2}{|c|}{$\begin{array}{c}\text { Unstandardized } \\
\text { Coefficients }\end{array}$} & $\begin{array}{c}\text { Standardized } \\
\text { Coefficients }\end{array}$ & \multirow{2}{*}{ Sig. } \\
\cline { 2 - 6 } & B & $\begin{array}{c}\text { Std. } \\
\text { Error }\end{array}$ & Beta & & \\
\hline 1 & (Constant) & .232 & .051 & & 4.550 & .020 \\
\hline & $\begin{array}{c}\text { Respirator } \\
\text { y Disease }\end{array}$ & $1.630 \mathrm{E}-5$ & .000 & .281 & .475 & .667 \\
\hline & Asthma & -.001 & .000 & -1.427 & -2.002 & .139 \\
\hline & $\begin{array}{c}\text { Pneumonia } \\
\text { Anerculos }\end{array}$ & .000 & .000 & 1.249 & 1.513 & .227 \\
\hline & $\begin{array}{c}\text { Tuberc } \\
\text { is }\end{array}$ & .000 & .731 & 1.394 & .258 \\
\hline & Meningitis & -.001 & .001 & -.564 & -1.258 & .297 \\
\hline & Measles & -.002 & .002 & -.765 & -1.096 & .353 \\
\hline \multicolumn{7}{|c|}{ a. Dependent Variable: SO2 } \\
\hline
\end{tabular}

Table 6 presents the Coefficients of the Multiple Regression for $\mathrm{SO} 2$ and diseases recorded in Oshimili South and North Local Government Areas. From the standardized coefficient values in Table 6 , the beta values are positive for Respiratory diseases, Pneumonia and Tuberculosis. This implies that as the emission of SO2 gases increases so also the prevalence of Respiratory diseases, Pneumonia and Tuberculosis increases.

Table 7: Coefficients of the Multiple Regression for H2S

\begin{tabular}{|c|c|c|c|c|c|c|}
\hline \multirow{2}{*}{\multicolumn{2}{|c|}{ Model }} & \multicolumn{2}{|c|}{$\begin{array}{l}\text { Unstandardized } \\
\text { Coefficients }\end{array}$} & \multirow{2}{*}{\begin{tabular}{|c|}
$\begin{array}{c}\text { Standardized } \\
\text { Coefficients }\end{array}$ \\
Beta
\end{tabular}} & \multirow[t]{2}{*}{$\mathrm{t}$} & \multirow[t]{2}{*}{ Sig. } \\
\hline & & B & Std. Error & & & \\
\hline \multirow[t]{7}{*}{1} & (Constant & -.004 & .074 & & -.050 & .963 \\
\hline & \begin{tabular}{|c|} 
Respirato \\
ry \\
Disease
\end{tabular} & 5.779E-5 & .000 & .850 & 1.165 & .328 \\
\hline & Asthma & .000 & .000 & -.348 & -.396 & .719 \\
\hline & $\begin{array}{c}\text { Pneumoni } \\
\text { a }\end{array}$ & $-1.681 \mathrm{E}-5$ & .000 & -.051 & -.050 & .963 \\
\hline & $\begin{array}{c}\text { Tubercul } \\
\text { osis }\end{array}$ & $4.272 \mathrm{E}-6$ & .000 & .142 & .220 & .840 \\
\hline & $\begin{array}{c}\text { Meningiti } \\
\mathbf{s}\end{array}$ & 3.877E-6 & .002 & .001 & .002 & .998 \\
\hline & Measles & -.001 & .003 & -.249 & -.289 & 791 \\
\hline & & e & dent Va & e: H2S & & \\
\hline
\end{tabular}

Table 7 presents the Coefficients of the Multiple Regression for H2S and diseases recorded in Oshimili South and North Local Government Areas. From the standardized coefficient values in Table 7, the beta values are positive for Respiratory diseases, Tuberculosis and Meningitis. This implies that as the emission of H2S gases increases so also the prevalence of Respiratory diseases, Tuberculosis and Meningitis increases.

\section{Table 8: Coefficients of the Multiple Regression for CO}

\begin{tabular}{|c|c|c|c|c|c|c|}
\hline \multicolumn{2}{|c|}{ Model } & \multicolumn{2}{|c|}{$\begin{array}{c}\text { Unstandardized } \\
\text { Coefficients }\end{array}$} & $\begin{array}{c}\text { Standardiz } \\
\text { ed } \\
\text { Coefficien } \\
\text { ts }\end{array}$ & Sig. & \\
\cline { 2 - 7 } & B & Std. Error & Beta & & \\
\hline 1 & (Constant) & -.042 & .032 & & -1.313 & .281 \\
\hline & $\begin{array}{c}\text { Respiratory } \\
\text { Disease }\end{array}$ & $3.148 E-5$ & .000 & .303 & 1.464 & .239 \\
\hline
\end{tabular}

\begin{tabular}{|l|c|c|c|c|c|c|}
\hline & Asthma & .001 & .000 & 1.121 & 4.495 & .021 \\
\hline & Pneumonia & .000 & .000 & -.484 & -1.678 & .192 \\
\hline & Tuberculosis & $-2.471 \mathrm{E}-5$ & .000 & -.539 & -2.938 & .061 \\
\hline & Meningitis & .002 & .001 & .546 & 3.480 & .040 \\
\hline & Measles & .002 & .001 & .293 & 1.201 & .316 \\
\hline
\end{tabular}

a.Dependent Variable: $\mathrm{CO}$

Table 8 presents the Coefficients of the Multiple Regression for $\mathrm{CO}$ and diseases recorded in Oshimili South and North Local Government Areas. From the standardized coefficient values in Table 8, the beta values are positive for Respiratory diseases, Asthma, Meningitis and Measles. This implies that as the emission of $\mathrm{CO}$ gases increases so also the prevalence of for Respiratory diseases, Asthma, Meningitis and Measles increases.

Table 9: Coefficients of the Multiple Regression forVOC

\begin{tabular}{|c|c|c|c|c|c|}
\hline \multirow{2}{*}{ Model } & \multicolumn{2}{|c|}{$\begin{array}{c}\text { Unstandardized } \\
\text { Coefficients }\end{array}$} & $\begin{array}{c}\text { Standardized } \\
\text { Coefficients }\end{array}$ & \multirow{2}{*}{ Sig. } & \\
\cline { 2 - 5 } & $\mathrm{B}$ & Std. Error & Beta & & \\
\hline (Constant) & 10.902 & 3.586 & & 3.040 & .056 \\
\hline $\begin{array}{c}\text { Respiratory } \\
\text { Disease }\end{array}$ & .001 & .002 & .217 & .378 & .730 \\
\hline Asthma & .022 & .018 & .830 & 1.200 & .316 \\
\hline Pneumonia & -.031 & .016 & -1.518 & -1.895 & .154 \\
\hline Tuberculosis & -.001 & .001 & -.456 & -.897 & .436 \\
\hline Meningitis & .036 & .079 & .200 & .459 & .677 \\
\hline Measles & .263 & .153 & 1.161 & 1.713 & .185 \\
\hline
\end{tabular}

a. Dependent Variable:VOCTable 9 presents the Coefficients of the Multiple Regression for VOC and diseases recorded in Oshimili South and North Local Government Areas. From the standardized coefficient values in Table 9 , the beta values are positive for Respiratory diseases, Asthma, Meningitis and Measles. This implies that as the emission of VOC gases increases so also the prevalence of for Respiratory diseases, Asthma, Meningitis and Measles increases.

\section{POLICY IMPLICATIONS/RECOMMENDATIONS}

Air pollution is a major environmental health problem, causing and inducing many adverse associated health effects that lead to excessive rate of annual morbidities and mortalities, especially in developing countries such as Nigeria. For this reason, air pollutions control is essential and should be a top priority of the government. Therefore, the policy makers and legislators in the country should amend all relevant laws and regulations, and also ensure there is coordination between different departments involving in air pollutions, which should be led by a powerful environmental protection organization.

The legislation and regulatory authorities should introduce an air quality framework that will require compliance monitoring, evaluation and assessment in Nigeria, and to ensure ambient air quality standards for protection of health are attain, maintain and met continually.

- Governmental institutions such as National Environmental Standards and Regulation Enforcement Agency (NESREA) or the Federal Ministry of the Environment should be enforced with statutory regulations and duties with regards to the protection of the Nigeria's environment such as the air quality. Such regulations should be adopted or re-introduced and strictly implemented which include the prohibition and other control measures restricting the pollutants from certain outdoor activities or from the vehicular emission

- The state government, as well as national agencies such as NESREA, should adopt environmental permitting system by setting out and enforcing management procedures such as regular reviews and assessments of air quality to 
identify whether the objectives have been, or will be, achieved at particular geographic locations where public health is, or will be, in jeopardy, by the applicable date that were introduced since the 1980 s, by the Nigerian Government as implementation of legislative requirements to attain stated air quality objectives.

- There is a need for proper air quality regulations since air quality standards and objectives are designed to protect public health, moreover, proposed legislation at the National Assembly on air pollution should incorporate the institution of regulations, which are designed with general scientific and expert consensus on the definition of the problem.

- There should be establishment of monitoring mechanisms, regulations, enforcement measures and emissions trading scheme for renewable energy, clean energy and cleaner air initiatives.

\section{CONCLUSION}

Air pollution exposure has devastating health effects as pollutant particles can penetratethe lungs and cardiovascular system, causing strokes, chronicobstructive pulmonary diseases and respiratory infections such as pneumonia.

It was also revealed in this study that the highest recorded gas emitted in the area was VOCs with $96.4 \%$, CO was $0.8 \%$, N2S was $0.4 \%$ while $\mathrm{SO} 2$ and NO2 were $1.2 \%$ each. NO2 exceeded the WHO and NAQS threshold. The gaseous pollutants showed high affinity with the prevalence of the associated diseases.

From the study, it was revealed that diseases related to air pollution are prevalent in the area of study, which ranges from Measles, Tuberculosis, Meningitis, Asthma, Pneumonia to respiratory diseases caused as dwellers inhaling small to large doses of NO2, SO2, H2S , CO and VOCs. These have contributed to number of hospistalisation cases and have had impacts on the livelihood of the people. Therefore, both the government and the corporate bodies should live up to the challenges of monitoring, evaluating and managing the air we breathe in the urban environment for a sustainable liveable city in the future not just for this generation but those yet unborn. Therefore, routine measurements should be made on a continuous basis to ascertain the volume of gaseous pollutants in the urban and rural environments

\section{REFERENCES}

1. Adejoke, C.O., Andile, M., \& Murembiwa, S.M. (2019). Health risks of exposure to air pollutants among students in schools in the vicinities of coal mines. Special Collection: Energy Exploration and Human Health, 37 (6), 1638-1656

2. Akpoghelie, J.O., Irerhievwie, G.O., Agbaire, P.O. \& Orisaremi, A. (2016). An assessment of air squality in sub - urban cities in Isoko, Delta State Nigeria. Journal of Emerging Trends in Engineering and Applied Sciences (JETEAS), 7(4): 179-185.

3. ATSDR (2016). Toxicological profile for hydrogen sulfide and carbonyl sulfide produced by the agency for toxic substances and disease registry, U.S. Department of Health and Human Services, Public Health Service in Atlanta, GA.

4. Atubi, A. O. (2011). Effects of Warri Refinery Effluents on Water Quality from the Iffie River, Delta State, Nigeria. American Review of Political Economy, 4556.

5. Atubi, A. O. (2012). Multivariate Analysis of the factors of socio-economic development of Nigeria: A case study of Delta State, Nigeria. Contemporary Journal of Social Sciences (CJSS) 1 \& 2:112-123.

6. Atubi, A. O. (2015a). Factors of environmental degradation in oil producing communities of Delta State, Nigeria. Journal of Agriculture and Environmental Sciences, 4(2), 58-70

7. Atubi, A. O. (2015b). Effects of oil spillage on human health in producing communities of Delta State, Nigeria. European Journal of Business and Social Sciences, 4(8), 14-30

8. Baumgartner, J. 1. (2014). Highway proximity and black carbon from cookstoves as a risk factor for higher blood pressure in rural China. PubMed.

9. Brooks, G.F., Carrol, K. C. Butel, J. S. \& Morse, S. A. (2007). Jawetz, Melnick, and Adelberg's Medical Microbiology 24th Edition. McGraw-Hill Publishing Company Inc. New York (pp. 145-160)

10. Colbeck, I., \& Lazaridis, M. (2010). Aerosol and environmental pollution. Biomed.Life Sci.97,117-131

11. Ghorani-Azam, A., Riahi-Zanjani, B., \& Balali-Mood, M. (2016). Effects of air pollution on human health and practical measures for prevention in Iran.J Res Med Sci., 21:65.

12. G adka, A., Rymaszewska,J., \& Zato ski, T. (2018). Impact of air pollution on depression and suicide. International Journal of Occupational Medicine and Environmental Health, 31(6), $711-721$ https: //doi. org/ 10. 13075/ ijomeh.1896.0127?
13. Gruzieva O, B. A. (2013). Exposure to air pollution from traffic and childhood asthma until 12 years of age.NCBI

14. Hathout, E. H. (2002). Role of exposure to air pollutants in the development of type 1 diabetes before and after 5 yr of age. PubMed.

15. Ibe, F.C., Opara, A.I., Njoku, P.C., \& Alinnor, J.I. (2017). Ambient Air Quality Assessment of Orlu, Southeastern, Nigeria. Journal of Applied Sciences, 17(9), 441-451

16. Landrigan, P. J., Fuller, R., Acosta, N. J. R., Adeyi, O., Arnold, R., Basu, N. N., \& Zhong, M. (2017).The Lancet Commission on pollution and health. The Lancet, 6736(17)32345

17. Lelieveld, J., Klingmuller, K., Pozzer, A., Poschl, U., Fnais, M., Daiber, A., \& Munzel, T. (2019). Cardiovascular disease burden fromambient air pollution in Europe reassessed using novel hazard ratio functions. European Heart Journal, 40, 1590-1596.

18. Menezes, J.A., Viana, G.F.D., \& Paes, C.R. (2012). Determinants of Lead exposure in children on the outskirts of Salvador, Brazil. Environ. Monit. Assess. 184,2593-2603

19. Nkwocha, E. E., Egejuru, R. O., Pat-Mbano, E. C., \& Njoku-Tony, R. F. (2011). Proximity of municipal waste dumpsite to residential neighborhoods and rate of hospitalization for malaria. Review in Infection (in press). 2012. Global Health Estimates Technical Paper WHO/HIS/HSI/GHE/2014.7. Available: http://www. who.int/entity/healthinfo/global burd en disease/GlobalCOD method 2000 2012.pdf. Accessed on 29 th November, 2015 .

20. Nwachukwu, A. N. 1., Chukwuocha, E. O., \& Igbudu, O. (2012). A survey on the effects of air pollution on diseases of the people of Rivers State, Nigeria. African Journal of Environmental Science and Technology, 6(10), 371-379.

21. Nwachukwu, A.N., \& Ugwuanyi, J.U. (2010). Air pollution and its possible health effects on rural dwellers in Rivers State, Nigeria. Afr.J. Phys.3,217-240.

22. Ogbija,T. E. (2014). Effects of environmental degradation on human health in selected oil communities in delta state. (Unpublished M.Sc Thesis, Delta State University, Abraka

23. Olajire, A.A., Azeez, L. \& Oluyemi, E.A. (2011). Exposure to hazardous air pollutants along Oba Akran road, Lagos-Nigeria. Chemosphere, 84(7): 10441051 .

24. Sun Z., \& Zhu D (2019) Exposure to outdoor air pollution and its human health outcomes: A scoping review.PLoS ONE 14(5), e0216550.

25. Ugwuanyi, J.U., \& Obi, F.C. (2002). A survey of health effects of air pollution on peasant farmers in Benue State, Nigeria. International Journal of Environmental Studies, 3(56), 234-543

26. Vlatka, G., Elvira, K.A. \& Josip, B. (2011). Influence of meteorological factors $\mathrm{NO} 2, \mathrm{SO} 2, \mathrm{CO}$ and PM10 on the concentration of $\mathrm{O} 3$ in urban atmosphere of Eastern Croatia. Environ. Monit. Assess. 16,491-501.

27. WHO (2014). Air quality and health, fact sheet No. 313, WHO Media Centre. Retrieved from http://www.who.int/mediacenter/factsheets/fs313/en/. Accessed October 10,2019

28. WHO (2018). Culled from aidforum.org/index.php/Topics/health-andwash/air-pollution-kills-7-million-each-year-90-of-which-are-in-lowincomecount, accessed May 3,2018.

29. William, R.K. (2012). Effects of air pollution on athlete health and performance.Br.J.Sports Med. 46, 407-412.

30. Willy,J.M.,Sherwood, M.L., \&Woolverton, C.J. (2008). Prescott, Harley and and Klein's microbiology. [Joanne M Willey; Linda Sherwood; Christopher J Woolverton;Lansing M Prescott]

31. World Health Organization (WHO) (2016) WHO releases country estimates on air pollution exposure and health impact. Available at: http://www.who.int/mediacentre/news/releases/2016/airpollutionestimates/en/ (accessed 24 January 2018).

32. Yelda A.T., \& Mustafa, $K$ (2011). Air pollutants and its effects on human healthy: the case of the city of Trabzon, advanced topics in environmental health and air pollution case studies, Prof. Anca Moldoveanu (Ed.), ISBN: 978$953-307-525-9$, I $\mathrm{T} \mathrm{e} \mathrm{ch,} \mathrm{A} \mathrm{v} \mathrm{a} \mathrm{i} \mathrm{a} \mathrm{b} \mathrm{l} \mathrm{e} \mathrm{f} \mathrm{rom}$ http://www.intechopen.com/books/advanced-topics-in-environmentalhealth-and-air-pollution-case-studies/airpollutants-and-its-effects-onhuman-healthy-the-case-of-the-city-of-trabzon 